Article

\title{
Inter-Korean Forest Cooperation 1998-2012: A Policy Arrangement Approach
}

\section{Mi Sun Park}

Program in Global Environmental Management, Seoul National University, Gwanakro 1, Gwanakgu, Seoul 151-921, Korea; E-Mail: mpark@snu.ac.kr; Tel.: +82-2-880-4928;

Fax: $+82-2-875-4763$

Academic Editor: Vincenzo Torretta

Received: 13 February 2015 / Accepted: 23 April 2015 / Published: 29 April 2015

\begin{abstract}
Despite political obstacles, South and North Korea have a history of conducting cooperative forest activities. Since 1999, the two Koreas have taken part in implementing cooperative forest projects, including reforestation, construction of tree nurseries, and control of insect pests, to achieve sustainability of the forests on the Korean Peninsula. This paper analyzes South Korean policies for inter-Korean forest cooperation, using a policy arrangement approach (PAA) with four dimensions: discourse, actors, rules of the game, and power. Policy changes by three South Korean administrations are analyzed: that of Kim Dae Jung (1998-2002), Roh Moo Hyun (2003-2007) and Lee Myoung Bak (2008-2012). The analysis focuses on an examination of the interactions among the four dimensions of policy arrangement and the policies of the administrations. This research indicates that change of the South Korean policy discourse to North Korea by the various administrations has fundamentally influenced actors and their resources, as well as the rules, in the field of inter-Korean forest cooperation. Insights from this analysis can contribute to the design of bilateral forest cooperation policies on the Korean Peninsula.
\end{abstract}

Keywords: policy arrangement; forest; cooperation; South and North Korea

\section{Introduction}

The Korean Peninsula was divided into South Korea (the Republic of Korea) and North Korea (the Democratic People's Republic of Korea) after the Korean War, which ended in 1953. While in the process of developing different systems (a capitalist market economy in South Korea and a centrally 
planned industrial economy in North Korea), South and North Korea continued to confront and conflict with each other for decades after the War. In 1995, South Korea began to provide food assistance to North Korea, which has long suffered from chronic food shortages and flood damage [1]. Since then, inter-Korean exchanges and cooperative activities have expanded over time in various fields. In particular, inter-Korean cooperative forest activities have continued for over ten years.

South Korea achieved forest recovery through effective reforestation policies in the 1970s [2]. The successful reforestation experience of South Korea is considered to be a good model for developing countries $[3,4]$. In contrast, forested areas in North Korea have steadily decreased over time [5], as energy and food shortages have caused increases in logging and accelerated deforestation in that country since the 1990s [6]. More recently, North Korea ranked 3rd in the 2012 deforestation index, released by risk analysis and mapping [7].

The problem of deforestation and forest degradation in North Korea is emerging as a problem for the entire Korean Peninsula. Deforestation and forest degradation in North Korea threaten the stability of ecosystems. It results in destructing habitats of wildlife such as bears and tigers [8] and increases vulnerability to climate change on the Korean Peninsula which causes floods and droughts [9]. Moreover, deforestation in North Korea affects the cost of Korean unification in the future, as reforestation there will require a huge financial investment, estimated at 32 trillion won (approximately 30 billion USD) [10,11]. For these reasons, current activities for reforestation in North Korea are necessary, in both environmental and economic dimensions.

In 1999, South Korea began to conduct inter-Korean forest cooperation (IKFC) activities for improving the environmental status of the Korean Peninsula. For more than ten years after that, three types of cooperative forest projects were implemented: reforestation, cultivation of saplings, and control of insect pests [12]. These projects were implemented in the specific areas of Pyongyang, Kaesong, and the Kumkang Mountains, as selected by North Korea [8]. South Korea offered materials for reforestation, including seeds, seedlings, fertilizers, pesticides, pruning scissors, and so on [13]. North Korea had responsibility for planting and managing trees in the reforestation projects. The areas reforested with fruit trees, such as apple trees and chestnut trees, were managed successfully for food. The projects to cultivate saplings were large scale, including construction of greenhouses and photovoltaic generating facilities in the Kaesong and Kumkang Mountain areas, Nasun, and Hoeryong [13-15]. Tree nurseries play a significant role in offering saplings for reforestation in North Korea. The projects to control insect pests were intended to solve insect problems shared by the two Koreas, and have been effectively and continuously implemented by both nations.

This paper examines the South Korean policies for IKFC, applying a policy arrangement approach (PAA) to analyze policy changes by three South Korean administrations: that of Kim Dae Jung (1998-2002), Roh Moo Hyun (2003-2007) and Lee Myoung Bak (2008-2012). The South Korean policy changes for IKFC were analyzed for four dimensions: discourse, actors, rules, and power/resources. The analysis reveals interactions among the four dimensions of policy arrangement and the policy differences of the various administrations, and concludes with recommendations for inter-Korean forest cooperation policies. This paper can contribute to the design of bilateral forest cooperation policies on the Korean Peninsula by providing significant insights through its analysis. 


\section{Policy Arrangement Approach: Research Design and Method}

Among the theories and methods applied to forest policy analysis are policy instruments [16-18], advocacy coalition frameworks [19,20], policy networks [21,22], and policy arrangement [23-25]. In this research, a policy arrangement approach (PAA) was applied to analyze South Korean policies for IKFC, as a specific method of policy analysis that examines policy practice changes and structural changes in contemporary society [26]. "Policy arrangement" is defined as "the temporary stabilization of the content and organization of a particular policy domain" [27] (p. 54). It includes structures formed through processes, as well as interactions among policy actors, and formal and informal rules [28]. A PAA has been applied to analyze changes of forest policies in several countries, such as in the Netherlands [23], Belgium [24] and South Korea [25]. As these studies demonstrate, a PAA is an appropriate way to describe the dynamics of policy changes with four interwoven dimensions: discourse, actors, the rules of the game, and resources or power. In policy arrangement, the discourse dimension refers to substantive aspects of policy, while the other three dimensions refer to the organizational aspects of policy [26].

Discourse is a shared way of comprehending the world [29]. It is defined as a set of ideas, concepts, and narratives that give meaning to a certain phenomenon or issue [23,29,30]. In forest policy, discourse contributes to identifying and interpreting forest problems or issues. Actors consist of members of society at various spatial levels. Actors include various stakeholders, including governmental organizations, non-governmental organizations (NGOs), international organizations, enterprises, citizens, and so on. Rules of the game mean procedures of decision-making and implementation, and include laws, ordinances, decrees, declarations, agreements, and policy plans, among other instruments. Resources are materials and knowledge for producing benefits. Resources to intervene or withdraw include money, information, technology, and materials [25]. The allocation of resources between the actors leads to differences in power to influence the policy process.

To investigate the dynamics of IKFC policies in South Korea, documents such as laws, ordinances, agreements, policy reports, and research articles on IKFC from 1998 to 2012 were collected and analyzed. Relevant information regarding forest cooperation between South Korea and North Korea was also collected from press releases and official websites of related public and private organizations. The information on IKFC was categorized in relation to the four dimensions of the PAA.

The period from 1998 to 2012 includes three South Korean administrations: that of Kim Dae Jung (1998-2002), Roh Moo Hyun (2003-2007), and Lee Myoung Bak (2008-2012). Thus, the differences in the IKFC policies of the various administrations can be compared in this research.

South Korean discourse on exchange and cooperation between South Korea and North Korea is described in this study on the basis of key terms that are frequently found in relevant documents, including Unification White Papers, from 1998 to 2012; in particular, "reconciliation and cooperation", "peace and prosperity", and "denuclearization and openness" were selected as key terms. The roles of public actors (central and local governments) and private actors (NGOs, enterprises and individuals), and the relationships among them are described. Actors that are analyzed herein are central governments (Ministry of Unification and Korea Forest Service), local governments (Geonggi and Gangwon Provinces), NGOs (Forest for Peace and Green One Korea), enterprises (Yuhan-Kimberly, POSCO, Kookmin Bank) and individuals. In particular, the creation of new associations or organizations is 
highlighted. The legal system, as it relates to the rules of the game for IKFC, was investigated. Inter-Korean declarations, agreements, and statutes at the national level, and ordinances at the local level are described and analyzed (Table 1). Power was interpreted based on actors' resources for IKFC, in four areas: finance, expertise, communication and networks, and legal authority. With limitations in terms of data collection and interpretation, resulting in a lack of data, the study could not extend analysis to North Korean policies for IKFC. Hence, this research on IKFC is South Korean-centric.

Table 1. List of the referenced legal and policy documents in the manuscript.

\begin{tabular}{cc}
\hline Type of Documents & Title of Documents \\
\hline Books & Unification White Papers (1998-2012) \\
Declarations \& & June 15 Joint Declaration (2000) \\
Agreements & $\begin{array}{c}\text { The 15th Inter-Korean Ministerial Talks (2005) } \\
\text { Declaration on the Advancement of South-North Korean Relations, Peace and Prosperity (2007) } \\
\text { Fcts }\end{array}$ \\
\hline First South-North Prime Ministerial Talks (2007)
\end{tabular}

\section{Results}

\subsection{Discourse}

The foci of South Korean policy discourse toward North Korea have evolved, as shown in Table 2. The Kim Dae Jung (KDJ) administration (1998-2002) promoted a reconciliation and cooperation policy, aimed at assuring peaceful coexistence between South Korea and North Korea by protecting peace and stability on the Korean Peninsula [31] (pp. 22-24). Under this policy, the two leaders of South Korea (President Kim Dae Jung) and North Korea (Chairman Kim Jong Il) signed the June 15 Joint Declaration in 2000. The leaders agreed to cooperation and exchanges in several fields, such as culture, sports and health, and environmental issues through the Declaration, in Article 4 [31]. The Declaration plays a significant role as a basic negotiation instrument for IKFC.

Table 2. Policy foci towards North Korea by the Korean administrations.

\begin{tabular}{ccc}
\hline South Korean Administration & Policy Focus toward North Korea & Forest Project Activities \\
\hline Kim Dae Jung (1998-2002) & Reconciliation and cooperation & Creation \\
Roh Moo Hyun (2003-2007) & Peace and Prosperity & Vitalization \\
Lee Myoung Bak (2008-2012) & Denuclearization and Openness & Stagnation \\
\hline
\end{tabular}


The Roh Moo Hyun (RMH) administration (2003-2007) initiated a policy for peace and prosperity, promoting peace on the Korean Peninsula, pursuing mutual prosperity for South Korea and North Korea, and contributing to prosperity in Northeast Asia [31]. Under the policy for peace and prosperity, the 15th Inter-Korean Ministerial Talks were held in June 2005 [32]. In these talks, North Korea and South Korea agreed to form and operate an Inter-Korean Agricultural Cooperation Committee led by vice-minister-level officials, to launch agricultural cooperation. In the first round of this committee, held in Gaeseong in August 2005, forestry projects were selected as one of five agricultural projects for inter-Korean cooperation [32]. South Korea and North Korea agreed to cooperate in the protection of lands and ecosystems through the construction of tree nurseries and control of diseases and insect pests. In addition, President RMH of South Korea and Chairman Kim Jong Il of the National Defense Commission of North Korea signed the Declaration on the Advancement of South-North Korean Relations, Peace and Prosperity on 4 October 2007. In the inter-Korean prime ministers' talks held for the implementation of the Declaration, South Korea and North Korea agreed to promote cooperation projects for reforestation and the prevention of diseases and insect pests [33].

The Lee Myoung Bak (LMB) administration (2008-2012) pursued denuclearization and openness (Vision 3000) for peaceful Korean unification, based on creative pragmatism [34]. The LMB administration gave highest priority to the resolution of the North Korea nuclear issue. The Vision 3000 initiative was introduced as a practical implementation strategy to realize denuclearization and an inter-Korean relationship, with mutual benefits and for common prosperity.

Comparing South Korean policies toward North Korea during the three administrations (Table 2), discourse on IKFC in the KDJ and RMH administrations was created, in support of the expansion of inter-Korean exchange and cooperation for mutual benefits and welfare in the two Koreas. IKFC was regarded as a humanitarian approach for a sustainable Korean Peninsula. In particular, discourse on IKFC in the RMH administration vitalized inter-Korean dialogues for inter-Korean exchange and cooperation (Table 3). South Korean policy toward North Korea during KDJ and RMH administrations, referred to as "Sunshine" policy [35], can be regarded as proactive policy to induce incremental and voluntary changes in North Korea for peace, opening and reform through a patient pursuit of reconciliation, exchanges, and cooperation [36] (p. 27). However, under the later LMB administration, discourse on IKFC was weakened, inter-Korean dialogues decreased, and inter-Korean exchanges and cooperation in most sectors, including forestry, were limited by the government.

Table 3. Declarations and agreements, including articles, on inter-Korean forest cooperation [31,34,37].

\begin{tabular}{cccc}
\hline Title & Signed Date & Contents & $\begin{array}{c}\text { South Korean } \\
\text { Administration }\end{array}$ \\
\hline June 15 Joint Declaration & 15 June 2000 & $\begin{array}{c}\text { Cooperation and exchanges } \\
\text { in the environmental field }\end{array}$ & $\begin{array}{c}\text { Kim Dae Jung } \\
(1998-2002)\end{array}$ \\
\hline $\begin{array}{c}\text { The 15th Inter-Korean } \\
\text { Ministerial Talks }\end{array}$ & 23 June 2005 & Inter-Korean agricultural cooperation & $\begin{array}{c}\text { Roh Moo Hyun } \\
(2003-2007)\end{array}$ \\
\hline
\end{tabular}


Table 3. Cont.

\begin{tabular}{cccc}
\hline Title & Signed Date & Contents & $\begin{array}{c}\text { South Korean } \\
\text { Administration }\end{array}$ \\
\hline $\begin{array}{c}\text { First round of Inter-Korean Agricultural } \\
\text { Cooperation Committee }\end{array}$ & 19 August 2005 & $\begin{array}{c}\text { Forestry projects: protection of } \\
\text { lands and ecosystems through the } \\
\text { construction of tree nurseries and } \\
\text { control of diseases and insect pests }\end{array}$ & $\begin{array}{c}\text { Roh Moo Hyun } \\
(2003-2007)\end{array}$ \\
\hline $\begin{array}{c}\text { Declaration on the Advancement } \\
\text { of South-North Korean Relations, } \\
\text { Peace and Prosperity }\end{array}$ & 4 October 2007 & $\begin{array}{c}\text { Cooperation projects in the } \\
\text { sector of agriculture and } \\
\text { environmental protection }\end{array}$ & $\begin{array}{c}\text { Roh Moo Hyun } \\
\text { (2003-2007) }\end{array}$ \\
\hline $\begin{array}{c}\text { First South-North Prime Ministerial } \\
\text { Talks for implementing Declaration on } \\
\text { the Advancement of South-North Korean } \\
\text { Relations, Peace and Prosperity }\end{array}$ & 16 November 2007 & $\begin{array}{c}\text { Cooperation projects on } \\
\text { reforestation and prevention } \\
\text { of diseases and insect pests }\end{array}$ & Roh Moo Hyun \\
\hline
\end{tabular}

\subsection{Actors}

Both public actors (central and local governments) and private actors (NGOs, enterprises and individuals) participated in establishing and implementing policies of IKFC. Multiple actors played different roles as supporters, practical actors, and collaborators in building IKFC (Figure 1).

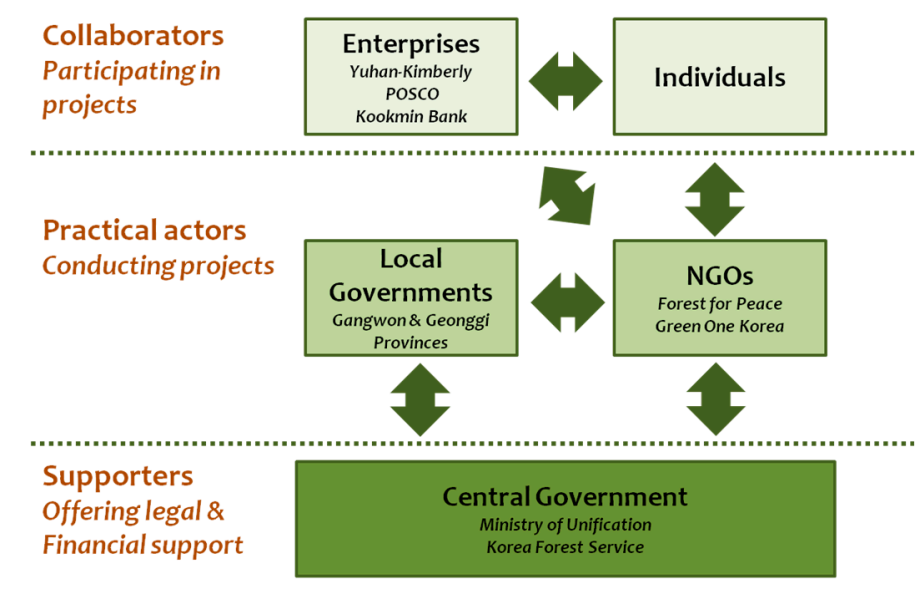

Figure 1. Multiple actors of inter-Korean forest cooperation projects.

Presidents and ministers of South Korea have negotiated with national representatives of North Korea for inter-Korean exchange and cooperation. They built multiple types of agreements for the IKFC. In the dimension of the central government, the Ministry of Unification and the Korea Forest Service (KFS) are in charge of inter-Korean forest cooperation in South Korea. The Ministry of Unification, which was established in 1969, is a governmental body with responsibility for all issues pertaining to inter-Korean relations and unification [38]. The Ministry of Unification establishes and coordinates policies regarding inter-Korean exchanges and cooperation, and offers the institutional framework for IKFC. It has established and implemented policy instruments, such as legislation, funds, and publications, the detailed contents of which are described in the next section (on rules and power). The KFS, which was established in March 1967, is a central government in forest management policies. Under the KFS, the Forest Resources Division has responsibility for IKFC policies, and establishes and implements strategies for IKFC. 
Gangwon and Geonggi Provinces (Figure 2), which share South Korean and North Korean borders, have conducted inter-Korean exchange and cooperation activities. Gangwon Province has focused on the collaborative control of diseases and insect pests [39]. Based on agreements for South-North Gangwon Province's cooperation [40] (pp.148-149), Southern Gangwon Province provided chemicals and equipment and Northern Gangwon Province provided trained forest technicians for the control of pine needle gall midge (Thecodiplosis japonensis) and black-tipped sawfly (Acantholyda posticalis posticalis). Since June 2001, control activities of pine needle gall midge were conducted in 11,100 ha of the region of Kumkang Mountain. Over 92 percent of the controlled areas were co-monitored by South-North Gangwon Province. Responding to the request by North Gangwon Province, South Gangwon Province controlled black-tipped sawfly in 8500 ha of North Gangwon Province, including in the cities of Wonsan, Tongcheon, and Anbyeol until 2008. Gyeonggi Province focused on the construction of nurseries for reforestation. It offered seeds, seedlings, equipment, chemicals, fertilizers, and technology, and North Korea managed nurseries for the cooperation projects [14].

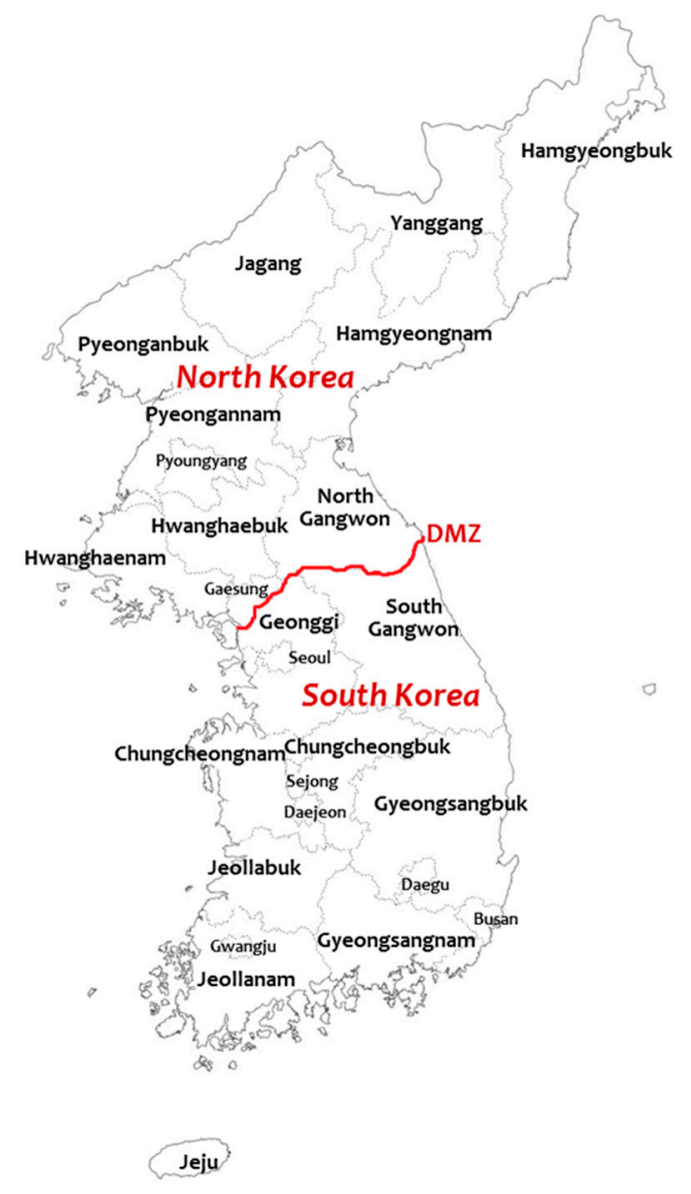

Figure 2. Map of the Korean Peninsula.

Forest for Peace (FFP), a non-governmental organization (NGO) for forestry, has conducted activities for reforestation in North Korea since 1999 [41]. Cooperation activities by FFP started with responding to North Korea's requests for materials, such as seeds and fertilizers. FFP supported the construction of tree nurseries in Pyongyang and Mount Kumgang and reforestation with Castenea crenata and Pinus densiflora and the control of control of the pine needle gall midge (Thecodiplosis japonensis) in the region of Mount Kumgang. In addition to FFP as a pioneer, several NGOs have conducted cooperative 
forest activities since 2003. Although the number of cooperative forest activities increased, inter-Korean forest cooperation has financial limitations because of the large-scale budget required. In 2007, during the RMH administration, a total of twenty NGOs, including the FFP, the Korean Council for Reconciliation and Cooperation, the Korean Sharing Movement, and so on, formed an integrated NGO, Green One Korea (GOK) [42]. GOK is a collective effort to expand and sustain inter-Korean forest cooperation. Based on the agreements for establishing and protecting forests in North Korea between GOK and the National Reconciliation Council of North Korea (March 2007), South Korea and North Korea collaborated on the construction of tree nurseries in Hoeryong, Hamkyungbukdo; Gaepoong, Hwanghaenamdo; Gosung, Gangwondo; and Pyongyang City. GOK also planted trees (Castanea crenata) in Pyongyang City, the region of Mount Kumgang and Gosung in Gangwon Province. It supported control of forest diseases and insect pests. Enterprises collaborating with NGOs, such as Forest for Peace, participated in the reforestation of North Korea. However, inter-Korean forest cooperation does not bring economic benefits to the enterprises that participate in forest-related activities in North Korea. In particular, a private enterprise, Yuhan-Kimberly, participated in reforestation projects in North Korea. Yuhan-Kimberly has led the forestry campaign called "Keep Green Korea" since 1984 [43]. It conducted the campaign through various governance types, such as donations, collaborations, and in-house projects. The campaign has included North Korea since 1999 [44]. Yuhan-Kimberly financially supported reforestation, the control of disease and insect pests, and the construction of tree nurseries jointly with FFP. From 2005 to 2008, it planted trees with newlyweds in Gosung-gun, North Gangwon Province. Moreover, another private company, "POSCO", donated 100 million Korean won (90 thousand USD) for a UNDP project for the construction of tree nurseries in North Korea in 2001 [41]. "Kookmin Bank" donated 400 million Korean won (361 thousand USD) for a project of FFP to construct tree nurseries in 2001 [41]. Under the KDJ and RMH administrations, several NGOs and enterprises participated in IKFC projects actively, joined by individuals.

As mentioned above, multiple actors contributed to building IKFC (Figure 2). The Ministry of Unification, a central government body, plays a core role as an institutional supporter through multiple policy instruments. As practical actors, local governments and NGOs implemented IKFC projects, and enterprises and individuals acted as collaborators, by donating to IKFC projects.

\subsection{Rules}

The rules for IKFC include declarations, agreements, laws, ordinances, and plans. The South Korean government has negotiated with national representatives from North Korea for inter-Korean exchange and cooperation. The South Korean government signed the inter-Korean summits declarations, which suggest principles for inter-Korean cooperation. There are three significant agreements regarding IKFC: the June 15 Joint Declaration in 15 June 2000, Inter-Korean Ministerial Talks in June 2005, and First South-North Prime Ministerial Talks for implementing the Declaration on the Advancement of South-North Korean Relations, Peace and Prosperity in October 2007 (Table 2). The agreements were concluded during the KDJ and RMH administrations and offer a logical and procedural basis for promoting inter-Korean cooperation projects on reforestation and the prevention of diseases and insect pests.

The South Korean government constructed a legal framework for forest cooperation between South Korea and North Korea. The South Korea government enacted the Guideline on Inter-Korean Exchanges 
and Cooperation on 12 June 1989 [1]. The Ministry of Unification established the Inter-Korean Exchange \& Cooperation Act in August 1990 and the Inter-Korean Cooperation Fund Act in September 1990. The Inter-Korean Exchange and Cooperation Act sets forth procedures for visits and cooperative projects between South Korea and North Korea. Based on the Inter-Korean Cooperation Fund Act, in March 1991, the Inter-Korean Cooperation Fund was established, and has operated to support mutual exchange and cooperation between South Korea and North Korea under the Inter-Korean Exchange and Cooperation Act.

In the forestry sector, Article 9 of the Framework Act on Forestry established by KFS indicates forest policies necessary to prepare for unification, as one basic direction of forest policies. The fourth (1998-2007) and fifth (2008-2017) National Forest Plans by KFS include policies for IKFC to build peace in the Korean Peninsula. The plans highlight conserving Baekdudaegan, the large mountain range forming the backbone of the Korean Peninsula and the core ecosystem shared by South and North Korea, and managing the Korean Demilitarized Zone (DMZ). The DMZ, which crosses the middle of the Korean Peninsula, is a mountainous area with rich biodiversity, including over 1100 plant species and around 50 mammal species [45]. However, collaborative policies between South Korea and North Korea have not been implemented in the areas of Baekdudaegan and DMZ. KFS did not formulate a specific law regarding IKFC.

At the local level in South Korea, a total of 58 ordinances, 15 decrees, and an instruction were established in the area of exchange and cooperation between South Korea and North Korea as of January 2015 [46]. South Gangwon Province established an Ordinance on South-North Gangwon Province's Exchange and Cooperation Committee in September 1989 and an Ordinance on South-North Gangwon Province's Cooperation Fund in December 1998 [40]. In addition, Gyeonggi Province established an Ordinance on South-North Gyeonggi Province's Exchange and Cooperation in 2001 and an Ordinance on Gyeonggi Province's Exchange and Cooperation Committee in March 2002. These ordinances create the legal basis for the process of establishing and implementing IKFC projects by the two Provinces.

The agreements for IKFC between South Korea and North Korea by the Provinces and NGOs are practical documents for initiating IKFC projects. The agreement for forestation and forest protection was concluded by South Gyeonggi Province and the North Korean Council for Reconciliation and Cooperation on 13 September 2007 [14]. The FFP concluded agreements for inter-Korean cooperation for constructing and protecting forests in North Korea with representative organizations of North Korea, including the Asia-Pacific Peace Committee (March 2000), the North Korea Forest Research Institute (March 2001), the Mount Kumgang Tour Corporation (February 2004, February 2006) and the Tourism Venue Development Bureau (February 2007) [41].

\subsection{Power}

Power is interpreted based on actors' resources for IKFC. Actors exercise their power in four areas: finance, expertise, communication and networks, and control. The South Korean government has strong administrative power for IKFC. South Korean administrations have negotiated with representatives of North Korea for exchange and cooperation between South Korea and North Korea through inter-Korean dialogues and agreements of various types. In particular, the political will of presidents as political leaders strongly influence South Korean policies toward North Korea. The Ministry of Unification of 
the central government exercises administration power through multiple policy instruments, such as regulations, plans, funds and education, for inter-Korean exchange and cooperation. The Ministry of Unification has the power to permit and reject IKFC projects, according to the Inter-Korean Exchange \& Cooperation Act. All IKFC projects must be approved by the Ministry of Unification. Access to North Korea is also controlled by the Ministry of Unification. Discourse on IKFC has influenced exchange and cooperation between South Korea and North Korea. The inter-Korean cooperation projects increased under the RMH administration, emphasizing peace and prosperity. However, under the LMB administration, the continuation of IKFC projects was not permitted because of the nuclear issue between South Korea and North Korea. The Ministry of Unification established and operated the Inter-Korean Cooperation Fund for supporting the mutual exchange and cooperation between South Korea and North Korea under the Inter-Korean Exchange \& Cooperation Act. Although exact data on governmental finance for all IKFC projects is not available, according to Article 8 of the Inter-Korean Cooperation Fund Act, the Ministry of Unification spent approximately 1.8 billion Korean won (1.9 million USD) from the Inter-Korean Cooperation Fund for the control of forest diseases and insect pests in 2007 [30]. The Ministry of Unification allocated the Inter-Korean Cooperation Fund for humanitarian assistance projects, including IKFC projects (Figure 3). Discourse on IKFC also influenced the allocation of financial resources to IKFC projects by private organizations, such as the FFP, GOK, and Korean Council for Reconciliation and Cooperation (Table 4). In the forestry sector, allocation of the Inter-Korean Cooperation Fund increased gradually during the RMH administration and decreased during the LMB administration, which prioritized denuclearization and openness. Fund allocation influences the direct implementation of IKFC projects by NGOs that depend on project finance from the Inter-Korean Cooperation Fund. Therefore, the Ministry of Unification exercises institutional power for inter-Korean forest cooperation activities by private organizations. In particular, the Ministry of Unification has the power to control IKFC projects by several actors. The Ministry of Unification transfers information on inter-Korean exchange and cooperation including IKFC through regular publications, such as Unification White Papers. However, most communication by the Ministry is one-way. There is a lack of exchange ideas and information on the issue of inter-Korean exchange and cooperation with multiple actors. Above all, the Ministry of Unification lacks professional expertise in forest sector. It needs collaboration with technical experts in designing and implementing forest cooperation projects.

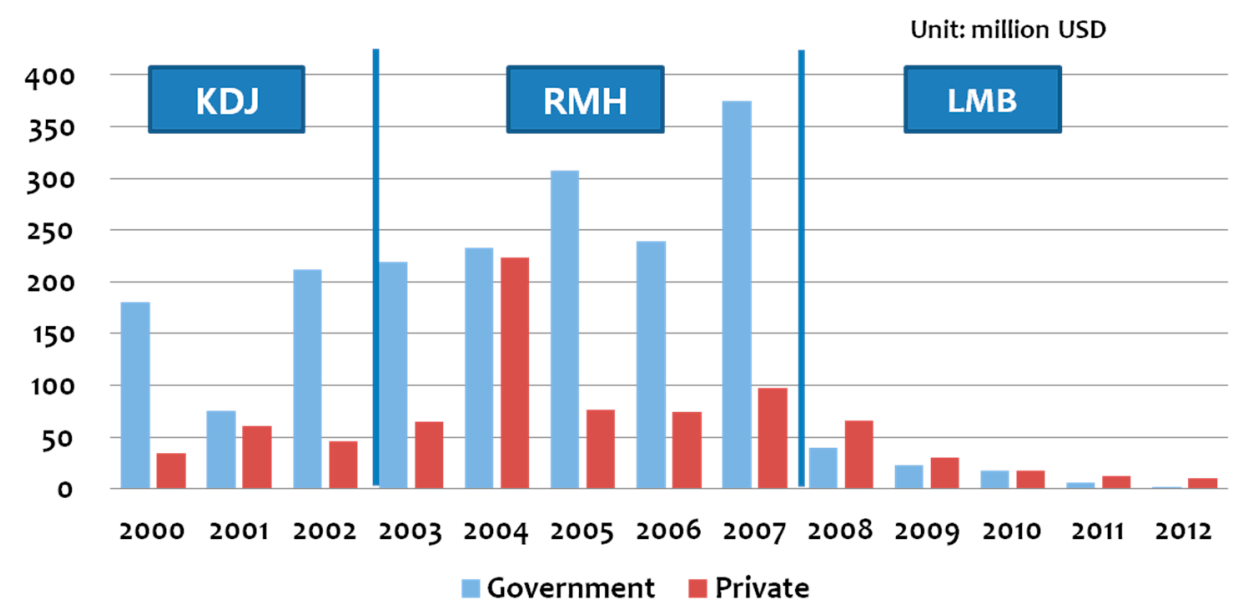

Figure 3. Government and private assistance and grants to humanitarian projects [47]. 
Table 4. The amount financed by the Inter-Korean Cooperation Fund for Inter-Korean forest cooperation activities [48].

\begin{tabular}{|c|c|c|c|c|c|c|c|}
\hline \multirow{4}{*}{ The Financed Private Organizations } & \multicolumn{6}{|c|}{ Year } & \multirow{4}{*}{ Total } \\
\hline & 2003 & 2004 & 2005 & 2006 & 2007 & 2008 & \\
\hline & \multicolumn{6}{|c|}{ Administration } & \\
\hline & \multicolumn{4}{|c|}{ RMH } & \multicolumn{2}{|r|}{ LMB } & \\
\hline Forest for Peace & 46 & 75 & 87 & 160 & 22 & - & 390 \\
\hline Korean Council for Reconciliation and Cooperation & - & - & - & - & 1399 & - & 1399 \\
\hline Green One Korea & & & & - & - & 338 & 338 \\
\hline Total & 46 & 75 & 87 & 160 & 1421 & 338 & 2127 \\
\hline
\end{tabular}

KFS has major power in South Korean forest policies, and successful experiences in South Korean reforestation [2]. In spite of excellent forest expertise, KFS established no specific institutional framework for IKFC, such as laws or funding. KFS as a subordinate organization under the Ministry for Food, Agriculture, Forestry and Fisheries has less administrative power in IKFC than the Ministry of Unification. KFS reviews feasibility of IKFC projects submitted by civil organizations to the Ministry of Unification and offers advice on forest technology and policies [8] (p. 103).

Local governments and NGOs have human resources with both forest expertise and inter-Korean cooperation experiences. They have established and implemented IKFC projects for several years. Through IKFC projects, they gained better knowledge and experiences on IKFC and built networks with North Korean partners. Local governments have the financial capacity for IKFC. Gangwon and Gyeonggi Provinces have established and administered South-North Gyeonggi Province's Cooperation Fund. On the other hand, the NGOs depend on governmental finance for IKFC. NGOs have stronger power in communication for IKFC than any other actors. NGOs have cooperated with scientists, enterprises, and other NGOs in establishing and implementing IKFC projects. They organized several conferences and symposia collaboratively with governmental agencies to communicate issues related to IKFC with the public and other actors. The power of enterprises in this context is limited, and they contribute their financial resources to the implementation of IKFC projects by NGOs.

\section{Discussion and Conclusions}

The political border between South Korea and North Korea cannot divide the ecosystem on the Korean Peninsula. The two Koreas share environmental disasters such as forest fires, pest diseases, and loss of biodiversity. Deforestation and forest degradation in North Korea threatens ecological stability throughout the Korean Peninsula. South Korea and North Korea must address these issues together to establish a sustainable Korean Peninsula [5]. Since 1999, the two nations have conducted IKFC projects that aim to halt deforestation and restore forests in North Korea. IKFC projects have contributed to establishing forests and controlling insect pests in portions of areas. In this study, the dynamics of South Korean policies for inter-Korean forest cooperation were interpreted within the context of four dimensions of policy arrangement. For fifteen years (from 1998 to 2012), discourse, actors, rules of the game, and power in the field of IKFC varied with South Korea's administrations. These four dimensions are interconnected each other. The different policy discourses of South Korea substantively influenced 
the other three dimensions of the PAA (actors, rules of the game, and power) in the field of IKFC. In South Korea, policy discourse on reconciliation and cooperation during the KDJ administration (1998-2002) induced a new system for IKFC. The June 15 Joint Declaration of 2000, a milestone in the history of inter-Korean exchange and cooperation, stimulated IKFC activities. Discourse on reconciliation and cooperation induced the establishment of ordinances on funds and committees for inter-Korean exchange and cooperation in Gangwon and Gyeonggi provinces, working as a basic rule for establishing and implementing IKFC projects in these two provinces. Based on discourse on reconciliation and cooperation, civil society created the FFP, the first civil organization focusing on IKFC in South Korea. Consequently, discourse on reconciliation and cooperation contributes to laying the foundation for IKFC.

Next, discourse on peace and prosperity between the two Koreas was constructed during the RMH administration (2003-2007), invigorating IKFC activities. At the national level, summit meetings and high-level talks between South Korea and North Korea increased. The meetings and talks resulted in a framework rule for allocating amounts of financial resources to IKFC by the public and private sectors and designing IKFC projects by local governments and NGOs as practical actors. In the process of establishing and implementing IKFC projects, the voluntary agreements between two Koreas functioned as a practical rule. However, the agreements excluded detailed plans for IKFC, and were broken easily and unilaterally by North Korea. IKFC projects have been conducted jointly by the various South Korean actors, however, including NGOs, scientists, and enterprises, and their network were consolidated. Consequently, discourse on peace and prosperity vitalized IKFC activities.

However, the discourse of the LMB administration (2008-2012) prioritized denuclearization and stagnated inter-Korean cooperation activities, including IKFC. The Ministry of Unification exerted administrative powers over IKFC, and reduced governmental financing for IKFC, restricting IKFC projects. The requirement for legal authoritisation by the Ministry of Unification was a barrier for continued IKFC projects. Under authority by the Ministry of Unification, the ordinances and agreements regarding IKFC were not applied, and private actors were powerless in implementing IKFC projects.

In this case study, the PAA approach is informative in revealing the power structure among actors. Figure 4 indicates the relative power of key actor groups, in the areas of finance, expertise, communications and networks, and legal authority, during three administrations. The assignment of actors' power to one of three levels- low, medium or high- is based on the research results reported in Section 3.4. As Table 5 indicates, financial power is classified with financial dependency and scale into the low (dependent), medium (independent and small scale) and high (independent and large scale). Forest expertise is classified with positioning of forest experts within organizations into the low (none forest experts), medium (part-time position) and high (full-time positions). Communication and networks are classified with communication activities and coalitions into low (no publications and no conferences), medium (publications and conferences) and high (publications, conferences and creation of coalitions). Legal authority is classified with legislations and administration procedures into low (no legislation and no control to projects), medium (establishing and implementing legislations) and high (establishing and implementing legislations and controlling projects). The Ministry of Unification had dominant power in financing and controlling IKFC projects during three administrations. Through laws, funds and administration procedure, the Ministry of Unification had control of IKFC. KFS, with a high level of forest expertise, exercised weak power in financing and controlling IKFC. However, it is necessary that KFS, as the central forest administration, leads IKFC policies. Local governments continued their power 
in all four dimensions under the control by the Ministry of Unification. NGOs, with combined forest expertise, had high power in communicating and building networks with other actors. In particular, NGOs exercised their power with the high level through building GOK, a civil network for IKFC during $\mathrm{RMH}$ administration. NGOs had weak power in financing IKFC projects during three administrations. Therefore, NGOs collaborated with enterprises that had financial power in implementing IKFC projects. Enterprises' power has been not high in IKFC; however, they are actors with latent power in financing IKFC projects.

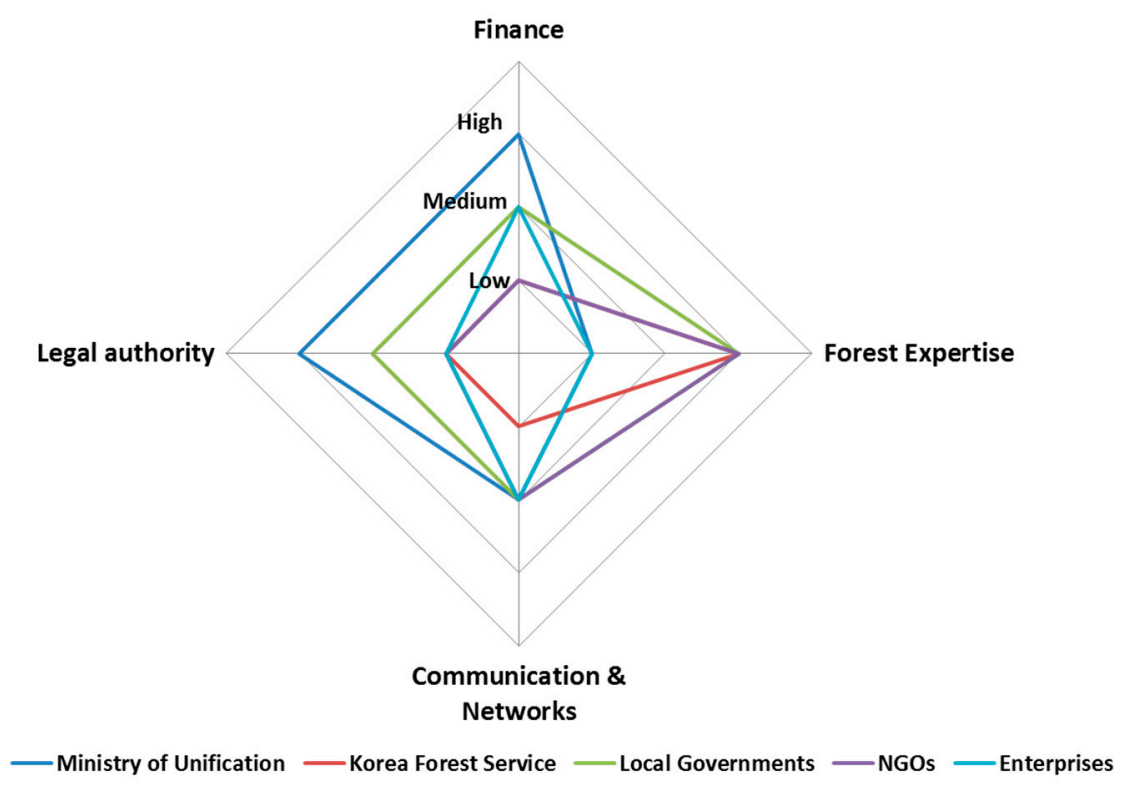

(a) KDJ Administration (1998-2002)

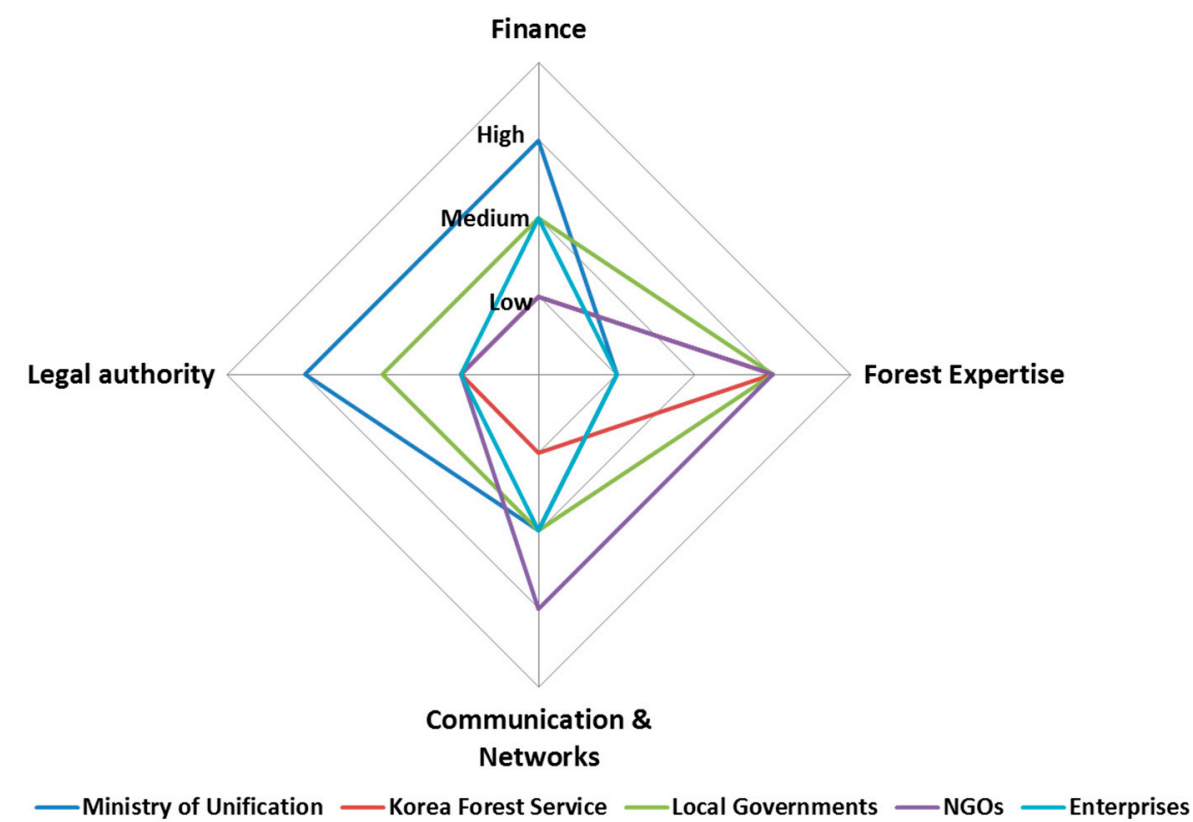

(b) RMH Administration (2003-2007)

Figure 4. Cont. 


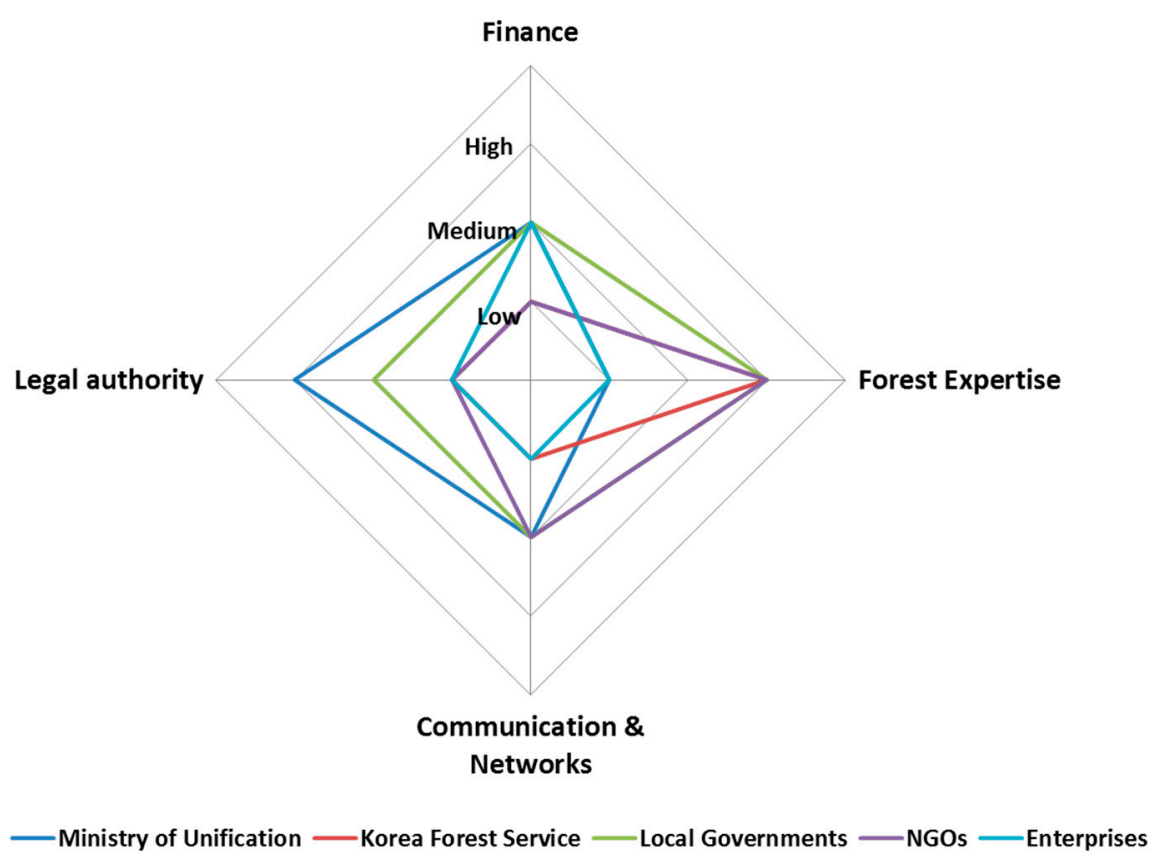

(c) LMB Administration (2008-2012)

Figure 4. Relative level (low, medium and high) of key actors groups in each of four dimensions of power by administrations.

Table 5. Classification of levels of power.

\begin{tabular}{|c|c|c|c|c|}
\hline \multirow{2}{*}{$\begin{array}{c}\text { Dimensions } \\
\text { of power }\end{array}$} & \multirow{2}{*}{ Attributes } & \multicolumn{3}{|c|}{ Levels } \\
\hline & & Low & Medium & High \\
\hline Finance & $\begin{array}{c}\text { Financial dependency } \\
\text { Financial scale }\end{array}$ & Dependent & $\begin{array}{c}\text { Independent and } \\
\text { small scale }\end{array}$ & $\begin{array}{c}\text { Independent and } \\
\text { large scale }\end{array}$ \\
\hline Forest expertise & $\begin{array}{c}\text { Positions of forest } \\
\text { experts within } \\
\text { organizations } \\
\end{array}$ & No forest experts & Part-time positions & Full-time positions \\
\hline $\begin{array}{l}\text { Communication } \\
\text { and networks }\end{array}$ & $\begin{array}{c}\text { Communication } \\
\text { activities } \\
\text { Coalitions } \\
\end{array}$ & $\begin{array}{l}\text { No publications } \\
\text { and no conferences }\end{array}$ & $\begin{array}{l}\text { Publications and } \\
\text { conferences }\end{array}$ & $\begin{array}{c}\text { Publications and } \\
\text { conferences } \\
\text { Coalitions } \\
\end{array}$ \\
\hline Legal authority & $\begin{array}{l}\text { Legislations } \\
\text { Administration } \\
\text { procedures }\end{array}$ & No legislations & $\begin{array}{l}\text { Establishing and } \\
\text { implementing } \\
\text { legislations }\end{array}$ & $\begin{array}{c}\text { Establishing and } \\
\text { implementing legislations } \\
\text { Controlling projects }\end{array}$ \\
\hline
\end{tabular}

This research indicates that change of the South Korean policy discourse to North Korea by the various administrations has fundamentally influenced actors and their resources, as well as the rules, in the field of inter-Korean forest cooperation. To continue to implement IKFC projects, it is necessary to have an institutional system that is less sensitive to policy discourse changes with changes in administrations.

Based on the results of the PAA herein, three recommendations are formulated for IKFC, to promote sustainability on the Korean Peninsula. The first is to establish a long-term Master Plan for IKFC that is agreed to by South Korea and North Korea. While several agreements between the two nations established IKFC projects, such as the project for the construction of tree nurseries and the control of 
forest insects, South Korea and North Korea have not yet agreed to a corporate plan to implement IKFC projects in stages. A Master Plan or Roadmap for IKFC should include goals, objectives, strategies, time, budgets, and so on. In light of the argument by critics that South Korea's aid to North Korea was a one-sided concession during the KDJ and RMH administrations [35] (p. 125), a Master Plan or Roadmap could identify the role of each of South Korea and North Korea for IKFC, and maximize the potential for mutually beneficial cooperation between them. For example, the Master Plan or Roadmap could include strategies for implementing intergovernmental agreements which both Koreas have signed, such as the United Nations Convention on Biological Diversity, the United Nations Framework Convention on Climate Change, and the United Nations Convention to Combat Desertification. Previous agreements between the Koreas are ambiguous in relation to the responsible organizations. The Master Plan or Roadmap, as the primary guideline for IKFC, must precisely describe the roles of responsible organizations from both nations. Currently, the Ministry of Unification has dominant power in negotiating IKFC between South Korea and North Korea. KFS, as central forest administration, can also work as a representative organization for IKFC, using its expertise in the field of forestry. With such changes and provisions, the Master Plan or Roadmap would increase the feasibility of implementing IKFC projects regardless of a change in administration.

The second recommendation is to extend participation of multiple actors in IKFC projects. Under the LMB administration, IKFC projects were blocked, and non-governmental organizations or individuals could not continue IKFC activities. In 2009, NGOs and scientists held press conferences to urge the government to reactivate an inter-Korean exchange and cooperation projects in the sector of agriculture, forestry, and animal husbandry as humanitarian projects [49]. The private actors recognized that the South Korean government should continue humanitarian projects in North Korea, notwithstanding political conditions. NGOs and enterprises have strong intentions to recover trust with North Korean partners and reactivate their IKFC projects [8]. Recently, in March 2014, civil society launched "Green Asia Organization", a civil organization that seeks to grow trees in Asia, including North Korea [10]. In spite of political obstacles, with a humanitarian approach, IKFC projects by private actors should continue to contribute to stability within the Korean Peninsula. Currently, most IKFC projects depend on government funding. Considering the limitation in the human and financial resources of governments, it is necessary that the government provide private actors, with financial resources and expertise, with more opportunities for implementing IKFC projects.

South Korea has successful experience with civil society, including enterprises, NGOs, and citizens, voluntarily donating money and time for establishing and managing urban forests in South Korea [25]. Similarly, a wider range of NGOs and enterprises with intentions to restore North Korean forests [8] can participate in and support IKFC projects. In addition, inter-governmental organizations (IGOs) can play a role as a bridge among actors in IKFC. In the early stage of IKFC, South Korean actors attempted to conduct IKFC projects indirectly through IGOs such as the UNDP. IGOs helped communication between South Korea and North Korea, and created channels for IKFC projects to be formulated and implemented, functioning as a catalyst for cooperation between the two Koreas [8]. Hence, a governance structure that includes cooperation between public and private actors, and between national and international actors, could contribute to enhancing the quantity and quality of IKFC.

The third recommendation is to integrate several sectors for IKFC. Until now, IKFC projects included only three types: afforestation and reforestation, the construction of tree nurseries, and the control of 
forest insects. However, the problem of deforestation is caused by multiple drivers, such as urbanization, the lack of energy and food, and so on [50]. To address the problem of deforestation, integrated projects are necessary, including the planting of trees and supply of energy and food. The case of South Korean experience in reforestation could serve as a good example for North Korea [5].

In conclusion, this research elucidated IKFC policies, with particular attention on the interconnectedness of the four dimensions of policy arrangement in South Korea. The research findings could help in the understanding of institutional changes in IKFC policies, and practical recommendations have been derived that could contribute to designing IKFC policies for avoiding deforestation and forest degradation on the Korean Peninsula. As this research excluded an analysis of North Korean policies for IKFC, collaborative research with North Korean experts, and informed by North Korean data and perspectives, is expected in the future.

\section{Acknowledgements}

A part of this work was presented at the 1st World Conference on North Korean Studies on 28 October 2014, in Seoul, the Republic of Korea. The author would like to thank Hyowon Lee from Seoul National University for reviewing the draft manuscript. Also the author thanks anonymous journal reviewers for their advices and valuable comments.

\section{Conflicts of Interest}

The author declares no conflict of interest.

\section{References}

1. Ministry of Unification. Unification White Paper; Ministry of Unification: Seoul, Korea, 1996. (In Korean)

2. Bae, J.S.; Joo, R.W.; Kim, Y.-S. Forest transition in South Korea: Reality, path and drivers. Land Use Policy 2012, 29, 198-207.

3. Noronha, R. Why is it so difficult to grow fuelwood. Unasylva 1981, 33, 4-12.

4. Brown, L.R. Plan B 3.0: Mobilizing to Save Civilization; W.W. Norton: New York, NY, USA, 2008.

5. Park, M.; Lee, Y. Forest policy and law for sustainability within the Korean Peninsula. Sustainability 2014, 6, 5162-5186.

6. Jo, J.H.; Koo, J.C.; Youn, Y.C. Economic feasibility of REDD project for preventing deforestation in North Korea. J. For. Soc. 2011, 100, 630-638. (In Korean)

7. Maplecroft. Climate Change and Environmental Risk Atlas 2012; Maplecroft: London, UK, 2011.

8. Kim, S.; Lee, D. Deforestation in North Korea will Cause Desertification of Korean Peninsula; Story Yoon: Seoul, Korea, 2014. (In Korean)

9. Myung, S.; Kim, J.; Lim, M.; Whang, S.; Son, K.; Ahn, J.; Kim, M.; Kang, S.; Joo, K.; Sung, S.; et al. A Study on Constructing a Cooperative System for South and North Koreas to Counteract Climate Change on the Korean Peninsula III; Korean Environmental Institute: Seoul, Korea, 2013.

10. Ilbo, D.-A. Reforestation of North Korea is precedent for Green Reunification. Available online: http://english.donga.com/srv/service.php3?biid=2014031930648 (accessed on 8 April 2015). 
11. Park, J. Northeast Asian Forest Cooperation in Global Society. In Proceedings of the International Symposium on Governance for Reforestation in Korean Peninsula, Seoul, Korea, 13 November 2014; pp. 42-53. (In Korean)

12. Park, M.; Youn, Y. The Korean governance: An Inter-Korean Forestry Cooperation. Available online: http://www.iufro.org/download/file/6115/4110/iwc10-abstracts_pdf (accessed on 27 April 2015).

13. Lee, J. Reforestation projects in North Korea by Forest for Peace. In Proceedings of Symposium on Inter-Korean Cooperation for Reforestation in North Korea, Seoul, Korea, 9 February 2010. (In Korean)

14. Cho, C. Greening North Korea through inter-Korean Exchange and Cooperation. In Proceedings of Symposium on Inter-Korean Cooperation for Reforestation in North Korea, Seoul, Korea, 9 February 2010. (In Korean)

15. Ahn, S. Outcomes and Plans of inter-Korea Forest Cooperation Projects by Green One Korea. In Proceedings of Symposium on Inter-Korean Cooperation for Reforestation in North Korea, Seoul, Korea, 9 February 2010. (In Korean)

16. Krott, M. Forest Policy Analysis; Springer: Dordrecht, The Netherlands, 2005.

17. Cubbage, F.; Harou, P.; Sills, E. Policy instruments to enhance multi-functional forest management. For. Policy Econ. 2007, 9, 833-851.

18. Van Gossum, P.; Arts, B.; Verheyen, K. "Smart regulation": Can policy instrument design solve forest policy aims of expansion and sustainability in Flanders and The Netherlands? For. Policy Econ. 2012, 16, 23-34.

19. Lertzman, K.; Rayner, J.; Wilson, J. Learning and change in the British Columbia forest policy sector: A consideration of Sabatier's advocacy coalition framework. Can. J. Polit. Sci. 1996, 29, 111-133.

20. Elliott, C.; Schlaepfer, R. The advocacy coalition framework: Application to the policy process for the development of forest certification in Sweden. J. Eur. Public Policy 2001, 8, 642-661.

21. Cashore, B.; Vertinsky, I. Policy networks and firm behaviours: Governance systems and firm reponses to external demands for sustainable forest management. Policy Sci. 2000, 33, 1-30.

22. Krott, M.; Hasanagas, N.D. Measuring bridges between sectors: Causative evaluation of cross-sectorality. For. Policy Econ. 2006, 8, 555-563.

23. Veenman, S.; Liefferink, D.; Arts, B. A short history of Dutch forest policy: The "de-institutionalisation" of a policy arrangement. For. Policy Econ. 2009, 11, 202-208.

24. Van Gossum, P.; Arts, B.; Wulf, R.; de Verheyen, K. An institutional evaluation of sustainable forest management in Flanders. Land Use Policy 2011, 28, 110-123.

25. Park, M.; Youn, Y. Development of urban forest policy-making toward governance in the Republic of Korea. Urban For. Urban Green 2013, 12, 273-281.

26. Liefferink, D. The Dynamics of Policy Arrangements: Turning Round the Tetrahedron. In Insititutional Dynamics in Environmental Governance; Arts, B., Leroy, P., Eds.; Springer: Dordrecht, The Netherlands, 2006; pp. 45-68.

27. Van Tatenhove, J.P.M.; Arts, B.; Leroy, P. Political Modernization and the Environment: The Renewal of Environmental Policy Arrangements; Kluwer Academic Publishers: Dorerecht, The Netherlands, 2000. 
28. Arts, B.; Leroy, P. Insititutional Dynamics in Environmental Governance; Springer: Dordrecht, The Netherlands, 2006.

29. Dryzek, J.S. The Politics of the Earth: Environmental Discourses; Oxford University Press: Oxford, UK, 1997.

30. Hajer, M.A. The Politics of Environmental Discourse: Ecological Modernization and the Policy Process; Clarendon Press: Oxford, UK, 1995.

31. Ministry of Unification. Peace and Cooperation: White Paper on Korean Unification 2001; Ministry of Unification: Seoul, Korea, 2001.

32. Ministry of Unification. Unification White Paper; Ministry of Unification: Seoul, Korea, 2006. (In Korean)

33. Ministry of Unification. Unification White Paper; Ministry of Unification: Seoul, Korea, 2008. (In Korean)

34. Ministry of Unification. White Paper on Korean Unification 2010; Ministry of Unification: Seoul, Korea, 2010.

35. Choi, J. Sunshine over a barren soil: The domestic politics of engagement identity formation in South Korea. Asian Perspect. 2010, 34, 115-138.

36. Moon, C.I. The Sunshine Policy and the Korean Summit: Assessments and Prospects. In The Future of North Korea; Akaha, T., Ed.; Routledge: London, UK, 2013; pp. 26-46.

37. Ministry of Unification. Unification White Paper; Ministry of Unification: Seoul, Korea, 2005. (In Korean)

38. Ministry of Unification. Available online: http://eng.unikorea.go.kr/content.do?cmsid=1826 (accessed on 22 January 2015).

39. Ganwon Province. Available online: http://uni.provin.gangwon.kr/cb/fd00.html (accessed on 22 January 2015). (In Korean)

40. Ganwon Province. A Giant Step toward the Bright Future: The Ten Year Course of Exchange and Cooperation between Southern and Northern Gangwon Province; Gangwon Province: Chunchen, Korea, 2010. (In Korean)

41. Forest for Peace. Available online: http://www.peaceforest.or.kr/bbs/board.php?bo_table= 002_bbs2 (accessed on 22 January 2015). (In Korean)

42. Green One Korea. Available online: http://www.greenonekorea.or.kr (accessed on 22 January 2015). (In Korean).

43. Chung, J.Y.; Youn, Y.C.; Cho, D.S. Evolutionary governance choice for corporate social responsibility: A forestry campaign case in South Korea. Int. J. Sustain. Dev. World Ecol. 2012, 19, 339-348.

44. Moon, H. Euhan Kimberly: Greening and greening in the region of Mount Kumgang, Hankoolilbo. Available online: http://news.naver.com/main/read.nhn?mode=LSD\&mid=sec\&sid1=101\&oid= 038\&aid $=0001944819$ (accessed on 27 April 2015). (In Korean)

45. Lee, S. A new paradigm for trust-building on the Korean Peninsula: Turning Korea's DMZ into a UNESCO World Heritage site. Asia Pac. J. 2010, 35, 2-10. (In Korean)

46. Enhanced local law and regulations information system, Korean Ministry of Security and Public Administration. Available online: http://www.elis.go.kr (accessed on 22 January 2015). (In Korean) 
47. Ministry of Unification. Major statistics in Inter-Korean relations. Available online: http://eng.unikorea.go.kr/content.do?cmsid=1822 (accessed on 29 January 2015). (In Korean)

48. Ministry of Unification. White Paper on Inter-Korean Cooperation Fund; Ministry of Unification: Seoul, Korea, 2008. (In Korean)

49. Jang, M. Urging aid to North Korea in the sector of agriculture, forestry and animal husbandry by civil associations and scientists. Voice of the People, 10 December 2009. Available online: http://www.vop.co.kr/A00000275042.html (accessed on 8 April 2015). (In Korean)

50. Geist, H.J.; Lambin, E.F. Proximate causes and underlying driving forces of tropical deforestation: Tropical forests are disappearing as the result of many pressures, both local and regional, acting in various combinations in different geographical locations. BioScience 2002, 52, 143-150.

(C) 2015 by the author; licensee MDPI, Basel, Switzerland. This article is an open access article distributed under the terms and conditions of the Creative Commons Attribution license (http://creativecommons.org/licenses/by/4.0/). 